\title{
IMPLEMENTATION ASSISTANCE WORKSHOP CURRICULUM 2013 IMPROVING TEACHER ABILITY IN MI (MADRASAH IBTIDAIYAH) TO MAKE PLAN OF LEARNING IN EAST DISTRICT OF JATITUJUH
}

\author{
Etty Jaskarti \\ STKIP SEBELAS APRIL SUMEDANG \\ etijaskarti@gmail.com
}

\begin{abstract}
The purpose of this study is to observe: 1) the final ability of MI teachers to make / compile RPP with discovery learning, problem based learning, and project based learning model according to the provision in the 2013 curriculum after being given the drill method using job sheet. 2) early ability of MI teachers to make / compile RPP with discovery learning model, problem based learning, and project based learning according to the provision in curriculum 2013 before being given practice / drill method using job sheet. Data collection during the workshop on Curriculum Implementation 2013 for 22 hours (3hari). Alternative strategy taken in this research using experimental method with Pre-Experimental Design form. While the design used One-Group Pretest-Posttest Design. In this design there are pretest before being treated, and posttest after being given treatment using drill method, the study population is all the participants of workshop on the implementation of curriculum 2013 which amounted to 34 MI teachers in one class. Posttest implemented towards the end of the workshop. Based on the results of the study and discussion are described as follows: 1) the final ability of MI teachers is good with average posttest 77,082 with variance 31,780 and Corelasi 0,934> $0,05.2)$ the initial ability of MI teachers is still in doubt with pretest averages of 55.440 and variance of 12,678 , better ending ability than initial ability and with Asymp.Sig (2-tailed) $=0.005<0.05$ means there is a difference in ability beginning and end. In the end, it can be concluded that the practice / drill method using job sheet in the workshop can improve the ability of MI teachers to arrange RPP with discovery learning, problem based learning, and project based learning model according to the provision in the 2013 curriculum, in other words the method of drill / drill classified effective in the preparation of RPP based on the provisions according to the curriculum 2013.
\end{abstract}

Keywords: training method / drill, RPP with discovery learning model, problem based learning, and project based learning

\section{INTRODUCTION}

DEPARTMENT OF RELIGION requested assistance to all widyaiswara PPPPTK ranks and lecturers of Higher Education who joined in Satker PPPPTK in West Java, and accompanied by local District Supervisor to menatar Curriculum 2013 with Curriculum of Curriculum Implementation Curriculum 2013 in all schools under the auspices of DEPARTMENT OF RELIGION West Java, covering all Madrasah Ibtidaiyah (MI) both public and private, Madrasah Tsanawiyah (MTs), Madrayah Aliyah (MA), with a training pattern of 30 hours for 4 days.

The 2013 curriculum is a phenomenal curriculum because of its passionate spirit. Its powerful advocates, developed in a relatively short time but have the desire to appear perfect. The idea is great, ideal, the model is very different, and certainly very ambitious. This impression is understood by ordinary people before there is an explanation from the Minister 
of Education and Culture, that the 2013 curriculum is an implementation of the RPJMN 2010-2014 (National Medium Term Development Plan). Curriculum Policy 2013 is an effort to consolidate the implementation of the National Education System which is one of the policies that reads for the improvement of the curriculum of primary and secondary education.

For beginners, understanding the essence of the 2013 curriculum is relatively difficult because it requires a high appreciation ability with high-level reason. We need to change teachers' mins from instant-thinking habits to "indicative" thinking. For example, if you as a teacher, usually in the learning process in the classroom, we perku measure improving the ability of learners only from the aspects of cognitive and skills. Learning outcomes can be known immediately. We recommend the Curriculum 2013, teachers are asked to also observe the tendency of the attitude of learners at any time, whereas the attitude aspect is generally indicative. However, we should also be grateful that the 2013 curriculum is a wellintentioned curriculum because it is an expression of all the good wishes to shape the best generation of the Indonesian nation in the future. Are we able to do it?

In this case the researcher in the worshop mentoring the implementation of the 2013 curriculum provides materials: Simulation of Scientific-Based Learning, Authentic Assessment Simulation, RPP Preparation, Creating Learning Media, Peer Teaching. During the lesson of the 2013 curriculum accompaniment training program with RPP preparation training materials, the drill using a job sheet with time of 22 hours in 3 days is inseparable from pretest and posttest assessment, attitude, knowledge and skill, but in data analysis here only using pretest and posttest only. The drill is a subsystem of the 2013 curriculum implementation guidance workshop which is a structured and scheduled activity, and provides opportunities for teachers to gain real experience in order to improve knowledge, attitudes and skills related to the level of knowledge of RPP Preparation.

Based on the situational analysis and the above problems, to find out how "The drill by using the Job sheet and the TEMATIC SD package book according to the TEMA class can improve the ability of MI teachers in making / preparing the RPP in accordance with the provisions of the 2013 curriculum in candy 65 of 2013 on standard process ?. The things that are the focus of this research is the improvement of the final ability of teachers on the preparation of RPP after being given the practice / drill method. In relation to only 1 class of training / workshop, the data collection was conducted during 22 hours of training (3hari) in 
the learning process using the drill / exercise method using job sheet and Primary School theme book package according to the class group.

Providing guidance on the implementation of the 2013 curriculum to teachers to understand the 2013 curriculum, which is a planning document that contains the objectives to be achieved, the content of the material and the learning experience to be undertaken by students, strategies and ways that can be developed, evaluations designed to gather information about the achievement of objectives, and the implementation of the documents designed in the form of real. The objectives and benefits of the Curriculum Implementation Workshop 2013 are as follows:

1. Provide information to teachers about the concept of a Scientific approach that essentially provides learners with the experience to acquire knowledge based on scientific methods independently, as this approach encourages or forces learners to observe, question, search data, summarize, and communicate the results.

2. Introduce Permendikbud number 65 of 2015 on Standard Process Chapter IV Implementation of Learning which explains that to strengthen the integrated and scientific thematic approach it is suggested to apply discovery / inquiry learning. To encourage learners to produce creative and contextual works, both individuals and groups, it is recommended to use a learning approach that produces project based learning.

3. Developing Learning Activities which contains the Introduction, Core and Closing steps. In the core activities of Permendikbud number 65 of 2013 on Standard Process Chapter IV Implementation of Learning provides opportunities for teachers to use discovery / inquiry learning model, problem based learning model, and project based learning model the steps to be followed and present in the core activities, the following should be in accordance with the model used and all of these are contained in the RPP which should be prepared by the teachers.

4. Target Achievement Achievement / Workshop on Curriculum Implementation Implementation 2013: MI, MTs and MA teachers in West Java are target for BDKDEPARTMENT OF RELIGION for the intellectual life of Indonesian nation through MI, MTs, and MA schools.

The success of learning of teachers is an improvement in their ability, is the achievement of the state of the change process that is the change of behavior as a result of interaction with the environment in the learning process. The success of learning can be known by evaluation because evaluation means the assessment of the level of ability of 
teachers to achieve the goals set in a program. The indicator of the success of learning as a benchmark in declaring that a teaching and learning process can be said to succeed: a) Absorption ability of learning materials to achieve high achievement, both individually and group (cognitive is knowledge), b) Behavior outlined in the purpose of learning has achieved by both individual and classical teachers (affective is Attitude). c) Skills in developing / creating a clear systematic RPP is an applied knowledge and attitude that must be understood by teachers properly and correctly. The drill method, this method is generally used to obtain a dexterity or skill from what has been learned. Drill in denotative is an action to improve skill and skill. As a method, drill is a way of teaching learners (teachers) to develop skills and skills and can develop attitudes and habits. Exercise or practice is a process of learning and getting used to being able to do something, (Abdul Majid, 2016).

Job Sheets are provided based on Discovery, Problem Based Learning and Project Based Learning models, which teachers should try to follow as they are the content of the Core Activity as the learning steps in the lesson plan. Learning by Job Sheet is not testing teachers, but training teachers, so teachers can think and work to understand the learning models desired by Curriculum 13. Training Implementation Method. Each teacher from each village from a nearby sub-district of a district is called to attend the 2013 Curriculum Implementation Assistance Training, and is placed in a school that is a KKM, if for MI, while for MTs and for MA se MGMP. With some material level with 30 hour training pattern. Teachers who exist in the place that has been determined from the ranks of the Department of Education, Supervisors and Lecturers / Widyaiswara who has been appointed by the Ministry of Religion. The table below is a training pattern in the workshop for the implementation of curriculum 2013 k-min mined source of kulon kecamatan jatitujuh regency majalengka.

\begin{tabular}{l|l|c} 
No & Training Materials & $\begin{array}{l}\text { Number } \\
\text { Hours }\end{array}$ \\
\hline 1 & Curriculum Implementation Policy 2013 & 2 \\
\hline 2 & Change of Mindset and Rationalization of Curriculum 2013 & 2 \\
\hline 3 & Analysis of SKL, KI, KD & 2 \\
\hline 4 & Analysis of Master's Books and Student Books & 2 \\
\hline 5 & Developing a Document 1 Curriculum & 2 \\
\hline 6 & Simulation of Scientific-Based Learning & 4 \\
\hline 7 & Authentic Assessment Simulation & 4 \\
\hline 8 & Preparation of RPP & 6 \\
\hline 9 & Creating Learning Media & 4 \\
\hline 10 & Peer Teaching & 30
\end{tabular}


Eligibility for Higher Education Lecturers, Lecturers who are able to manage the subject of education and subject matter have been trusted by a training institution of PPPPTK, SEAMEO QITEP in Science, LPMP is authorized to run MIN, MTs, MAN under the auspices of DEPARTMENT OF RELIGION. The relationship between Lecturers in Higher Education with this type of activity, in general, the lecturer has followed the socialization of curriculum at national and regional levels.

\section{METHOD}

The method used in this research is experimental research method with PreExperimental Designs design with One-Group Pretest-Posttest Design and is a research used to find the effect of treatment (treatment) specified in the sample. The type and source of this research data is primary data. Primary data is data obtained directly by researchers in conducting their research, data obtained before the learning (pretest) and the end of learning (posttest) using the method of drill / exercise at the Curriculum Implementation Workshop 2013 in Sumber Kulon Village, Jatitujuh Sub-district Majalengka Regency. Taken 2 data pretest and posttest result which is the ability of beginning and end only. The sample used is the workshop participants amounted to 34 teachers.

Table 1. Identification of variables

\begin{tabular}{l|l|l}
$\begin{array}{l}\text { Dependent variable (Y) } \\
\text { End-ability of MI Posttest }\end{array}$ & $\begin{array}{l}\text { Dependent variable (Y) } \\
\text { End-ability of MI Posttest } \\
\text { teachers }\end{array}$ & $\begin{array}{l}\text { Dependent variable (Y) } \\
\text { End-ability of MI } \\
\text { Posttest teachers }\end{array}$ \\
\hline Independent variables (X) & Independent variables (X) & $\begin{array}{l}\text { Independent variables } \\
\text { Early ability of MI Pretset }\end{array}$ \\
$\begin{array}{l}\text { Early ability of MI Pretset } \\
\text { teachers }\end{array}$ & teachers & Pretset teachers
\end{tabular}

The analysis steps are:

The normality test is performed to determine whether the data is from a normally distributed population. A homogeneity test was conducted to find out whether two samples were taken to have a homogeneous variance or not. In this homogeneity test used Levene test with 5\% significance level. Hypothesis used in homogeneity test of variance. Because of the same sample then use Wilcoxson test with 5\% significance level. 


\begin{tabular}{|c|c|c|}
\hline \multicolumn{3}{|l|}{ Statistics } \\
\hline \multicolumn{3}{|l|}{$\bar{X}$} \\
\hline \multirow[t]{2}{*}{$\mathrm{N}$} & Valid & 34 \\
\hline & Missing & 0 \\
\hline \multicolumn{2}{|l|}{ Mean } & 55.4412 \\
\hline \multicolumn{2}{|c|}{ Std. Error of Mean } & .61065 \\
\hline \multicolumn{2}{|l|}{ Median } & 55.0000 \\
\hline \multicolumn{2}{|l|}{ Mode } & 55.00 \\
\hline \multicolumn{2}{|c|}{ Std. Deviation } & 3.56065 \\
\hline \multicolumn{2}{|c|}{ Variance } & 12.678 \\
\hline \multicolumn{2}{|l|}{ Range } & 10.00 \\
\hline \multicolumn{2}{|l|}{ Minimum } & 50.00 \\
\hline \multicolumn{2}{|l|}{ Maximum } & 60.00 \\
\hline \multicolumn{2}{|l|}{ Sum } & 1885.00 \\
\hline \multirow[t]{3}{*}{ Percentiles } & 25 & 55.0000 \\
\hline & 50 & 55.0000 \\
\hline & 75 & 60.0000 \\
\hline \multicolumn{3}{|l|}{ Statistics } \\
\hline \multicolumn{3}{|l|}{$\mathrm{Y}$} \\
\hline \multirow[t]{2}{*}{$\overline{\mathrm{N}}$} & Valid & 34 \\
\hline & Missing & 0 \\
\hline \multicolumn{2}{|l|}{ Mean } & 77.0882 \\
\hline \multicolumn{2}{|c|}{ Std. Error of Mean } & .96680 \\
\hline \multicolumn{2}{|l|}{ Median } & 78.0000 \\
\hline \multicolumn{2}{|l|}{ Mode } & 84.00 \\
\hline \multicolumn{2}{|c|}{ Std. Deviation } & 5.63736 \\
\hline \multicolumn{2}{|l|}{ Variance } & 31.780 \\
\hline \multicolumn{2}{|l|}{ Range } & 19.00 \\
\hline \multicolumn{2}{|l|}{ Minimum } & 65.00 \\
\hline \multicolumn{2}{|l|}{ Maximum } & 84.00 \\
\hline \multicolumn{2}{|l|}{ Sum } & 2621.00 \\
\hline \multirow[t]{3}{*}{ Percentiles } & 25 & 74.0000 \\
\hline & 50 & 78.0000 \\
\hline & 75 & 84.0000 \\
\hline
\end{tabular}

The mean difference test is intended to determine whether the average experiment class data differs significantly with the mean of the control class data. If the data is normally distributed and the variance is homogeneous then the test is done by $\mathrm{t}$ test. As for normal distributed data but not having homogeneous variance then the test using $\mathrm{t}$ 'test. And for data that is not normally distributed then the test manggunakan nonparametrik test that is using Mann-Whitney test.

Test t-testberger (dependent), This test is used to determine whether there is difference in the average value of two groups of data paired. Paired here means that one sample gets different treatment from time dimension. To analyze two samples correlated with the type of interval / ratio data, two-t test is used. The design of hypothesis testing is to know the difference of pretest and post test value on the drill method. 


\section{T-Test}

Paired Samples Statistics

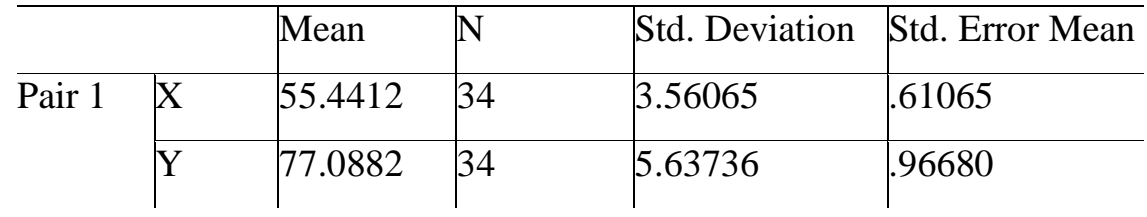

Paired Samples Correlations

\begin{tabular}{l|l|l|l}
\hline & $\mathrm{N}$ & Correlation & Sig. \\
\hline Pair 1 X \& Y & 34 & .934 & .000 \\
\hline
\end{tabular}

\section{Paired Samples Test}

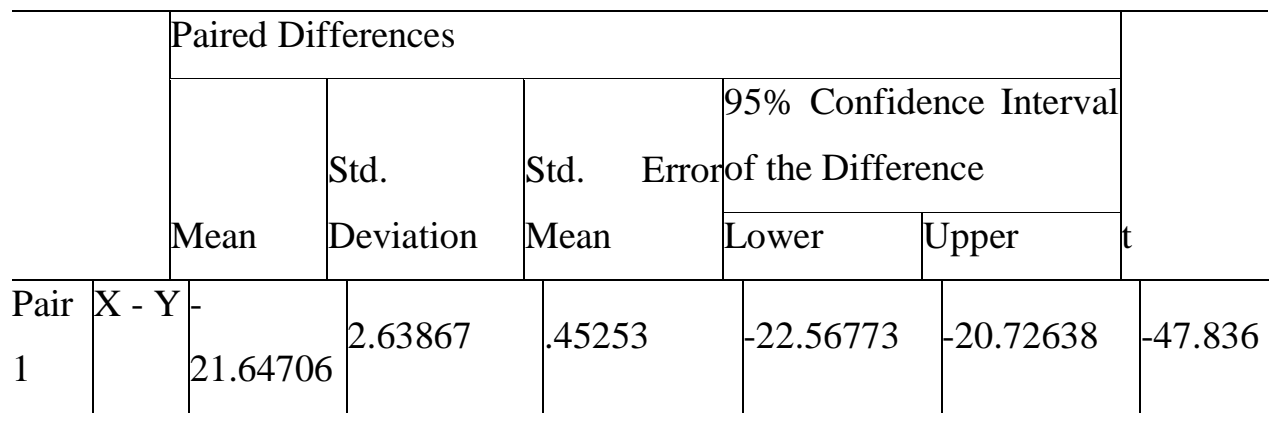

From the above table it can be seen that the average value before the practice / drill (pretest) method is 55.44 with a minimum value of 50 and a maximum value of 60 and a variance value of 12.678. While the average value after the practice / drill (posttest) method of 77.088 with a minimum value of 65 and a maximum value of 84 and the value of variance of 31.780. The variance difference is large enough to indicate homogeneous data, and correlation $0.934>0.05$. it can be concluded that in observation of pretest and posttest data that mean difference of 21,648 and variance difference of 19,102 there is significant difference of ability of MI teacher before and after practice / drill method.

Determination of Criteria Test, Test criteria conducted to determine the boundaries in making acceptance / rejection of the proposed hypothesis. The test criteria performed are as follows:

1) Degree of freedom $(\mathrm{dk})=\mathrm{n} 1+\mathrm{n} 2-2$.

2) The real level $\alpha=0.05 .3$ ) Test 2 parties. 


\begin{tabular}{|c|c|c|c|}
\hline \multicolumn{4}{|c|}{ One-Sample Kolmogorov-Smirnov Test } \\
\hline & & $X$ & $Y$ \\
\hline $\mathrm{N}$ & & 34 & 34 \\
\hline \multirow[t]{2}{*}{ Normal Parameters ${ }^{\mathrm{a}, \mathrm{b}}$} & Mean & 55.4412 & 77.0882 \\
\hline & Std. Deviation & 3.56065 & 5.63736 \\
\hline \multirow[t]{3}{*}{ Most Extreme Differences } & Absolute & .255 & .184 \\
\hline & Positive & .255 & .142 \\
\hline & Negative & -.245 & -.184 \\
\hline \multirow{2}{*}{\multicolumn{2}{|c|}{$\begin{array}{l}\text { Test Statistic } \\
\text { Asymp. Sig. (2-tailed) }\end{array}$}} & .255 & .184 \\
\hline & & $1.000^{\mathrm{c}}$ & $.005^{\mathrm{c}}$ \\
\hline
\end{tabular}

Based on the calculations in the table using SPSS program version 23 which is seen from the Kolmogorov-Smirnov One-Sample Test table it can be concluded that in observation of pretest and posttest data has significance value (Asymp.Sig.2-tailed) for Y 0.005 less than $0.05(5 \%)$, meaning that both data are not normally distributed. Because the normality requirement is not fulfilled, the hypothesis test is Wilcoxon Signed Rank Test. This test is used to determine whether there are differences in the ability of teachers before and after the practice / drill method.

The wilcoxon test is used to analyze the results of paired observations from two different whether or not data. Wilcoxon signed Rank This test is used only for data that does not follow the normal distribution and type of interval or ratio. Based on the calculation of the above table Asymp.Sig. (2-tailed) is obtained $0.000<$ from 0.05 which means there is a difference in the ability of teachers after and after the practice / drill method, this indicates that the drill method with job sheet and Thematic Sd book effectively gives a real influence in improving ability teachers in preparing RPP.

\section{RESULTS AND DISCUSSION}

This research was conducted in the class during the Training on Curriculum Implementation Implementation 2013 on 13,14,15,16 August 2015 in Sumber Kulon Village, Jatitujuh Sub-district Majalengka Regency, many participants attending the Curriculum Implementation Workshop 2013 are 34 MI Teachers. (4jp), Preparation of RPP (6jp), Creating Learning Media (4jp), Peer Teaching (4jp) amounted to 22 jp for 3 days for the material that the researcher gave, the Simulated Learning-Based Scientific (4jp), Authentic Assessment Simulation (4jp). 
Table 2. Assessment of Learning Process by drill method

\begin{tabular}{|c|c|c|c|}
\hline \multirow[b]{2}{*}{ No } & \multirow[b]{2}{*}{ Rated aspect } & \multicolumn{2}{|c|}{ amount } \\
\hline & & $\begin{array}{l}\text { Total number of } \\
\text { teachers }\end{array}$ & Percentage $(\%)$ \\
\hline 1 & $\begin{array}{l}\text { Participation } \\
\text { Full Presence } \\
\text { Not present }\end{array}$ & $\begin{array}{l}34 \\
0\end{array}$ & $\begin{array}{l}100 \\
0\end{array}$ \\
\hline 2 & $\begin{array}{l}\text { Knowledge (Cognitive) } \\
\text { Pretest } \\
\text { Posttest }\end{array}$ & $\begin{array}{l}34 \\
34\end{array}$ & $\begin{array}{l}100 \\
100\end{array}$ \\
\hline 3 & $\begin{array}{l}\text { Skills (Psychomotor) } \\
\text { Highly Skilled to make RPP with } \\
\text { Computer } \\
\text { Skilled enough to make RPP with } \\
\text { Computer } \\
\text { Highly Skilled Media } \\
\text { Skilled enough to create Media } \\
\text { Skilled in Peer Teaching }\end{array}$ & $\begin{array}{l}18 \\
16 \\
26 \\
8 \\
34\end{array}$ & $\begin{array}{l}52,94 \\
47,05 \\
76,47 \\
23,52 \\
100\end{array}$ \\
\hline 4 & $\begin{array}{l}\text { Attitude (Affective) } \\
\text { Active } \\
\text { Simply On } \\
\text { Not active }\end{array}$ & $\begin{array}{l}28 \\
6 \\
0\end{array}$ & $\begin{array}{l}82,35 \\
17,64 \\
0\end{array}$ \\
\hline
\end{tabular}

Participation is a mental and emotional involvement as well as the participant (teachers) in responding to the activities of the 2013 Curriculum Implementation Workshop and supporting the achievement of the workshop objectives. The participation shown in the above table is $100 \%$ with full attendance for 22 hours. For statistical analysis only used Prestest and Posttest.

Table 3 Pretest value data

\begin{tabular}{c|l|l|l|c} 
Value Group & Value interval & \multirow{2}{*}{ Category } & Amount & \\
\cline { 4 - 5 } & & & Frequency & $\%$ \\
\hline 1. & & & - & - \\
\hline 2. & $76-80(\mathrm{~A}-)$ & Gery good & - & - \\
\hline 3. & $71-75(\mathrm{~B}+)$ & Good & - & - \\
\hline 4. & $66-70(\mathrm{~B})$ & Enough & - & - \\
\hline 5. & $61-65(\mathrm{~B}-)$ & Enough & - & 70,58 \\
\hline 6. & $56-60(\mathrm{C}+)$ & Enough & 10 & - \\
\hline 7. & $45-55(\mathrm{C})$ & Less & 24 & -
\end{tabular}




\begin{tabular}{c|l|l|c|c}
\multirow{2}{*}{ Value Group } & Value interval & \multirow{2}{*}{ Category } & Amount & \\
\cline { 4 - 5 } & & & Frequency & $\%$ \\
\hline 1. & $81-100(\mathrm{~A})$ & Very good & 10 & 29,41 \\
\hline 2. & $76-80(\mathrm{~A}-)$ & Good & 9 & 26,47 \\
\hline 3. & $71-75(\mathrm{~B}+)$ & Good & 9 & 26,47 \\
\hline 4. & $66-70(\mathrm{~B})$ & Enough & 4 & 11,76 \\
\hline 5. & $61-65(\mathrm{~B}-)$ & Enough & 2 & 5,8 \\
\hline 6. & $56-60(\mathrm{C}+)$ & Enough & - & - \\
\hline 7. & $45-55(\mathrm{C})$ & Less & - & - \\
\hline 8. & $26-44(\mathrm{D})$ & Less & - & -
\end{tabular}

\section{CONCLUSION}

1. The method of drill is effective and gives a real effect in improving the ability of teachers in making RPP based on the provisions of curriculum 2013.

2. 2013 Curriculum Implementation is in need of conducive conditions and the creation of a school culture depends on the willingness of the principal.

3. Curriculum 2013 is an educational system that is loaded with character education, then the success of the Curriculum 2013 is determined by the exemplary culture that develops in schools.

4. The 2013 curriculum requires a culture of initiative in developing schools. Teachers without being supervised or motivated, take the initiative to improve themselves in carrying out learning according to the demands of the Curriculum 2013.

\section{ACKNOWLEDGMENTS}

Researchers would like to thank all those who have supported this research both in terms of morale and material, especially at the STKIP Selebelas April Sumedang.

\section{REFERENCES}

Ahmad Y. 2013. Mindset Kurikulum 2013. Alfabetha , Bandung

Brady,L. 1990. Curriculum Development. New York, London, Toronto, Sydney, Prentice Hall.

Hunkins, Francis P. 1980. Curriculum Development Program Improvement.Columbus, Toronto, London, Sydney, A Bell \& Howell Company.

Kemendibud, 2014. Panduan Pelatihan Implementasi Kurikulum 2013, Jakarta, BPSDM. , 2014. Tematik Terpadu Kurikulum 2013, Jakarta, PUSKURBUK.

Majid. A. 2016. Strategi Pembelajaran. Bandung. Rosdakarya

Sanjaya, W. 2008. Kurikulum dan Pembelajaran. Jakarta. Kencana Media Group.

, 2015. Strategi Pembelajaran Berdasarkan Standar Proses. Jakarta. Media Group.

Trianto. 2007. Model-model Pembelajaran Inovatf Berorientasi Kontruktivis, Surabaya Publiser. 